\title{
Financially distressed companies, restructuring and creditors' interests: what is a director to do?
}

\author{
Andrew Keay*
}

\begin{abstract}
It is a principle of $U K$ law that, when companies are financially distressed to the point of being insolvent or close to it, the directors of such companies are required to take into account the interests of creditors. This is now codified in the Companies Act 2006, s.172(3). In recent times there has been concern emitted by some commentators that directors might be unfairly held liable under s.172(3) for losses to creditors if a restructuring of a financially distressed company that they instituted failed. This paper examines whether such concerns are realistic and explores how directors should act if they decide to restructure their company's affairs.
\end{abstract}

\section{INTRODUCTION}

It is argued by some that creditors who provide credit to companies are not deserving of any special protection provided by law, because they are able to protect themselves by other means such as provisions in contracts, obtaining guarantees from shareholders and/or directors, the taking of security, or the inclusion of loan covenants. ${ }^{1}$ Yet others dissent and argue that creditors are deserving of some protection in some circumstances. Particular creditors, it is argued, such as trade creditors, lack adequate bargaining power to be able to secure reasonable terms that provide them with protection. ${ }^{2}$ Whatever one thinks of the view that creditors do not require special protection, over the years there have been several attempts to safeguard the interests of creditors and others from the actions of directors. Some of these measures have been well received, such as wrongful trading (certainly at the time of its inception at least), and others not so. Some of the measures

\footnotetext{
* Professor of Corporate and Commercial Law, Centre for Business Law and Practice, School of Law, University of Leeds, and Barrister, Kings Chambers and 9 Stone Buildings (Lincoln's Inn). A previous version of this paper was presented at the Chancery Bar Association on 29 November 2018 at the Inner Temple.

1. See North American Catholic Educational Programming Foundation Inc v Gheewalla (2007) 930 A 2d 92 , 100 (Del); S Rousseau, "The Duties of Directors of Financially Distressed Corporations: A Quebec Perspective of the Peoples Case" (2003) 39 CBLJ 368, 382; B Adler and M Kahan, "The Technology of Creditor Protection" (2013) 161 U of Pennsylvania L Rev 1773, 1775.

2. A Keay, "Directors' Duties to Creditors: Contractarian Concerns Relating to Efficiency and OverProtection of Creditors" (2003) 66 MLR 665, 696-698.
} 
have ended up being of questionable benefit to creditors, and wrongful trading probably falls into that category, given the many criticisms directed towards it. ${ }^{3}$

One form of protection is now found in s.172(3) of the Companies Act 2006 ("the Act"). ${ }^{4}$ This subsection confirms the common law developments that have taken place over the past 40 years and which provide that the directors' duty to promote the success of the company provided for in s.172(1) is, in certain circumstances, subject to an obligation to take into account the interests of the creditors. The circumstances are when their company is insolvent, near to the point of insolvency or in significant financial difficulties. While the duty, now encapsulated in s.172(3), was used infrequently during the 1980s and 1990s in the UK, there is now a reasonable corpus of cases that have been decided in this century and that indicates that liquidators have relied on this duty quite often in proceedings initiated against directors, ${ }^{5}$ and have been successful in a majority of the reported cases. The rationale for this obligation imposed on directors is often seen as the fact that, if a company is insolvent or close to it, the company is operating with the creditors' funds and that the creditors can be perceived to be the residuary beneficiaries of the company; ${ }^{6}$ the fact that companies should not trade at the expense of their creditors is "a recognised social principle in the business community"?

Given the case law that has developed in relation to wrongful trading claims, one leading London law firm has said that directors should be able to navigate successfully the risks posed by wrongful trading. ${ }^{8}$ However, can directors do so in respect of the duty to account for creditors' interests in s.172(3)? This question is particularly pertinent when it comes to restructuring of companies outside of formal insolvency regimes. Technically, restructuring involves an arrangement between a company and its shareholders, but it has come to be used frequently in relation to the restructuring of debt and as a synonym for rescue. Directors are regularly encouraged to enter into some form of restructuring of their company if it is suffering solvency problems and to avoid the company's falling into some formal insolvency procedure such as administration; ${ }^{9}$ there is a clear universal trend

3. See eg C Cook, "Wrongful Trading-Is it a Real Threat to Directors or a Paper Tiger" [1999] Insolvency Lawyer 99; A Walters, "Enforcing Wrongful Trading-Substantive Problems and Practical Incentives", in BAK Rider (ed), The Corporate Dimension (Jordans, Bristol, 1998); R Schulte, "Enforcing wrongful trading as a standard of conduct for directors and a remedy for creditors : the special case of corporate insolvency" (1999) 20 Co Law 80; A Keay, Company Directors' Responsibilities to Creditors (Routledge-Cavendish, Abingdon, 2007); A Keay, "Wrongful trading : problems and proposals" (2014) 65 NILQ 63.

4. The Scottish Court of Session (Inner House) in Joint Liquidators of Grampian Maclennan's Distribution Services Ltd v Carnbroe Estates Ltd [2018] CSIH 7 perceived it as a protective mechanism.

5. See eg Liquidator of West Mercia Safetywear v Dodd (1988) 4 BCC 30; Facia Footwear Ltd (in administration) v Hinchliffe [1998] 1 BCLC 218; Re Pantone 485 Ltd [2002] 1 BCLC 266; Colin Gwyer v London Wharf (Limehouse) Ltd [2002] EWHC 2748 (Ch); [2003] BCC 885; Re MDA Investment Management Ltd [2003] EWHC 227 (Ch); [2004] EWHC 42 (Ch); [2005] BCC 783; Re Cityspan Ltd [2007] EWHC 751 (Ch); [2008] BCC 60; Re Idessa (UK) Ltd [2011] EWHC 804 (Ch); [2012] BCC 315; Roberts v Frohlich [2011] EWHC 257 (Ch); [2012] BCC 407; [2011] 2 BCLC 625; Re HLC Environmental Projects Ltd [2013] EWHC 2876 (Ch); Ball v Hughes [2017] EWHC 3228 (Ch).

6. S Schwarcz in "Rethinking a Corporation's Obligations to Creditors" (1996) 17 Cardozo L Rev 647; Keay, Company Directors' Responsibilities to Creditors (2007).

7. P Davies, "Directors' creditor-regarding duties in respect of trading decisions taken in the vicinity of insolvency" (2006) 7 EBOR 301, 327 and referring to the Report of the Review Committee on Insolvency Law and Practice (London, HM Stationery Office, 1982) (Cork Report), [205-223].

8. Clifford Chance, "The role of directors in a restructuring: is it getting tougher?" (2015) CRI 208, 208.

9. Ibid. 
to foster corporate rescue,$^{10}$ and this is manifested in several reports, articles and opinions. There are the European Commission's relatively recent publications on restructuring, such as "A new European approach to business failure and insolvency" a Directive of the European Parliament and of the Council on preventive restructuring frameworks, second chance and measures to increase the efficiency of restructuring, insolvency and discharge procedures and amending Directive 2012/30/EU". ${ }^{12}$ Support for rescue is found in the report Rescue of Business in Insolvency Law, published by the European Law Institute, ${ }^{13}$ as well as the rationale for the enactment of the Enterprise Act 2002 in the UK. ${ }^{14}$ Also recently we have seen a response from the Department of Business Energy and Industrial Strategy to proposals published in $2016^{15}$ to support restructuring and which suggest that the bulk of the proposals will be encapsulated in legislation. ${ }^{16}$ Courts, ${ }^{17}$ practitioners and academics ${ }^{18}$ have all supported rescue at various times. Many have lauded restructuring as optimal and beneficial, ${ }^{19}$ as it means that the company survives and continues to trade, and this can benefit stakeholders, ${ }^{20}$ and particularly employees who keep their jobs and suppliers who can retain a customer to whom they can supply their goods. Moreover, rescue is seen as enhancing the wider economy, ${ }^{21}$ and it can be attractive to the state as it promotes economic growth. ${ }^{22}$ If restructuring can take place outside of a formal insolvency process, then costs may be saved and there may be other possible advantages, such as limiting the publicity of the company's distress. Some have questioned the efficiency of restructuring, ${ }^{23}$ with it being noted that the

10. J Adriaanse, "The Uneasy Case for Bankruptcy Legislation and Business Rescue" (2014) 2 Nottingham Insolvency and Business Law e-Journal 8, 8; D Morrison and C Anderson, "Is Corporate Rescue a Realistic Ideal? Business as Usual in Australia and the United Kingdom" (2015) 3 NIBLeJ 23, 24.

11. (COM) (2014) 1500 final.

12. (COM) (2016) 723 final.

13. B Wessels and S Madaus, Rescue of Business in Insolvency Law (European Law Institute, 2017): www. europeanlawinstitute.eu/fileadmin/user_upload/p_eli/Publications/Instrument_INSOLVENCY.pdf.

14. Inter alia, this endeavoured to make administration more effective and as a vehicle to restructuring.

15. Review of the Corporate Governance Framework (May 2016): assets.publishing.service.gov.uk/ government/uploads/system/uploads/attachment_data/file/525523/A_Review_of_the_Corporate_Insolvency_ Framework.pdf.

16. Insolvency and Corporate Governance: Government Response (26 August 2018): assets.publishing. service.gov.uk/government/uploads/system/uploads/attachment_data/file/736207/ICG_-_Government_ response_doc_-_24_Aug_clean_version_with_Minister_s_photo_and_signature_AC_final.pdf .

17. Eg, see Re Welfab Ltd [1990] BCC 600, 604.

18. Eg, R Maslen-Stannage, "Directors' duties to creditors: Walker v Wimborne revisited" (2013) 31 Company and Securities LJ 76, 78; M Epeoglou, "Comments on Commission's Proposal for a Directive on Preventive Restructuring Frameworks and Second Chance for Entrepreneurs : The Third Step to the European Cross-border Insolvency Saga" 14 International Corporate Rescue 4, 6.

19. S Gilson, J Kose, and H Lang, "Troubled Debt Restructurings: An Empirical Study of Private Reorganisation of Firms in Default" (1990) 27 J of Financial Economics 411, 412; L. Weiss, "Bankruptcy Resolution : Direct Costs and Violation of Priority Claims" (1990) 27 J of Financial Economics 285, 288.

20. L Lo Pucki and W Whitfield, "Corporate Governance in the Bankruptcy Reorganization of Large Publicly Held Companies" (1993) 14 U of Pennsylvania L Rev 669, 752. The authors argue that, if restructuring does not occur, then it could lead to the externalisation of costs to the detriment of non-creditor stakeholders.

21. European Commission, Recommendation Impact Assessment (Accompanying the Recommendation on A New Approach to Business Failure and Insolvency) SWD (2014) 61, 26.

22. S Paterson, "Bargaining in Financial Restructuring: Market Norms, Legal Rights and Regulatory Standards" (2014) 14 JCLS 333, 338.

23. See eg J Routledge and D Gadenne, "Financial distress, reorganization and corporate performance" (2000) 40 Accounting and Finance 233, 234. 
resources expended in formulating a rescue can be so great that sometimes the result is a pyrrhic victory only; ${ }^{24}$ and others have observed that, for a restructuring to be successful, someone will have to be worse off. ${ }^{25}$ Nevertheless, this paper will proceed, for the sake of argument, on the premise that restructuring is a worthwhile pursuit for a company in financial distress.

While the issue of whether a director is liable under s.172(3) is very fact sensitive, the cases decided in the UK generally fall into two broad categories. ${ }^{26}$ First, where directors have sought to self-deal, perhaps involving a transfer of company assets or funds to themselves or associates, perhaps even to repay a debt that they are owed by the company. ${ }^{27}$ Secondly, where they have either turned a blind eye to their company's financial malaise or failed to appreciate the predicament in which their company finds itself. ${ }^{28}$ But some have expressed disquiet that there might be, at least potentially, a third kind of case that is even more problematic. This is where directors have engaged in some attempt to restructure their company's ailing position and it fails and the company enters administration or liquidation. ${ }^{29}$ Directors might be concerned that, if their efforts fail, and actions are brought against them, judges will, with the benefit of hindsight, say that the outcome of the (failed) restructuring means that they neglected to fulfil the obligation contained in s.172(3). There seems to be no reported case where this has occurred in the UK, but this does not mean that the concern is not valid, as there is always going to be some risk in negotiating and seeking to implement a restructuring. As Sir Richard Scott V-C acknowledged in Facia Footwear Ltd (in administration) v Hinchliffe, ${ }^{30}$ "the boundary between an acceptable risk that an entrepreneur may properly take and an unacceptable risk ... is not always, perhaps not usually, clear cut". The issue of liability in a restructuring revolves around a tension between, on the one hand, wanting to ensure that companies survive if possible, which will benefit all involved, and, on the other hand, ensuring that creditors are protected to a certain, or reasonable, degree.

The fact is that s.172(3) might be applauded in that it could ensure that creditors do not lose out from directorial actions that are rash, incompetent or designed to protect directors and their associates, when a company is insolvent or heading for insolvency. Where a company's position is plainly untenable most would agree that directors should be seeking to minimise creditor losses. However, it is not uncommon for the position of the company or its future to be unclear. This means that directors are faced with a dilemma. When faced with financial difficulties, do they place the company in administration or liquidation, the effect of which is, for the most part, to terminate the

24. P Okoli, "Rescue culture in the United Kingdom: realities and the need for a delicate balancing act" (2012) 23 ICCLJ 61, 61.

25. See D Brown, Corporate Rescue (Wiley, Chichester, 1996), 2.

26. There is a minority of cases, such as Colin Gwyer v London Wharf (Limehouse) Ltd [2002] EWHC 2748 (Ch); [2003] BCC 885, that do not fit into either of the categories.

27. See eg Liquidator of West Mercia Safetywear v Dodd (1988) 4 BCC 30; GHLM Trading Ltd v Maroo [2012] EWHC 61 (Ch); Re HLC Environmental Projects Ltd (in liq) [2013] EWHC 2876 (Ch); Ball v Hughes [2017] EWHC 3228 (Ch); Joint Liquidators of CS Properties (Sales) Ltd [2018] CSOH 24.

28. See eg Roberts $v$ Frohlich [2011] EWHC 257 (Ch); [2012] BCC 407.

29. See eg A Hargovan and J Harris, "For Whom the Bell Tolls: Directors' Duties to Creditors after Bell" (2013) 35 Sydney L Rev 433. See also INSOL International, Directors in the Twilight Zone IV (London, 2013), x. 30. [1998] 1 BCLC 218, 228. 
incurring of more debt, or do directors continue on and embrace the idea of restructuring their company? In this regard unease is often emitted that in many cases directors may be so concerned about liability that they take their company into administration or liquidation prematurely. ${ }^{31}$ It is not always clear whether ending a company's business and placing it in administration or liquidation is in the best interests of the creditors; it certainly may not be in the best interests of the shareholders. However, continuing the company's business and seeking a restructuring could exacerbate the plight of creditors, because at the very least the company is likely to have incurred professional costs associated with possible restructuring and these costs can be, as the Carillion affair shows, very high. ${ }^{32}$ If restructuring is actually implemented but fails in the short or medium term, creditor losses can be even more significant.

On the basis that restructuring is a potentially beneficial exercise, some commentators, primarily in Australia ${ }^{33}$ but also in the UK and internationally, ${ }^{34}$ have expressed concern that directors may be dissuaded from considering restructuring options for fear of subsequent actions being taken against them if their efforts come to naught and their company enters either administration or liquidation. This paper examines whether the aforementioned concerns are realistic, given the law, and, if they are, what directors should be doing to ensure that they do not breach the obligation in relation to creditors. These are important matters, as little consideration has been given in the UK to the issue of liability of directors for breach of duty in the wake of an attempted restructuring. ${ }^{35}$

After briefly explaining the development of the duty to consider the interests of creditors, followed by a relatively short section on what restructuring can entail, the paper identifies the problems that exist for directors whose company might be in financial distress as this relates inextricably to the concerns over whether actions might be taken against directors engaged in restructuring. In this context the paper examines the issues that directors will need to consider when contemplating a restructuring process in light of the obligations that directors have to creditors. Next there is a discussion of the celebrated Australian case of Bell Group Ltd (in liq) v Westpac Banking Corp (No 9), ${ }^{36}$ which involved actions brought against directors of companies who restructured a group of companies. This is followed by an assessment of director liability for entering into restructuring arrangements. Finally, there are some concluding remarks.

31. See the comments of Lynch J in the Irish case of Re Hefferon Kearns Ltd (No 2) [1993] 3 IR 191 and those of Park J in the wrongful trading case of Re Continental Assurance of London Plc [2001] BPIR 733, [281].

32. For instance, what was expended in some attempts to restructure Carillion just before its fall into liquidation: "Carillion paid out $£ 6.4$ mill to advisors before $£ 10$ mill taxpayer bailout", available at www.parliament.uk/ business/committees/committees-a-z/commons-select/work-and-pensions-committee/news-parliament-2017/ carillion-advisors-comment-17-19/(12 March 2018).

33. See eg Hargovan \& Harris (2013) 35 Sydney L Rev 433; Arnold Bloch Leibler, Submission to the Productivity Commission, Business Set-up, Transfer and Closure (February 2015), 12-13: available at www.pc.gov. au/inquiries/completed/business/submissions.

34. See INSOL International, supra, fn.29, vi-vii.

35. For instance, one of the leading texts on restructuring, B Hedger and C Howard, Restructuring Law and Practice, 2nd revised edn (LexisNexis, London, 2014) discusses the obligation in s.172(3) in general terms but does not provide specific application of the provision to the restructuring scenario. The authors might provide, quite rightly, by way of riposte that the law tends to be uncertain and therefore it is not possible to be specific, especially in a general text.

36. [2008] WASC 239; affd [2012] WASCA 157. 


\section{THE OBLIGATION TO TAKE ACCOUNT OF CREDITORS' INTERESTS}

It is not intended to rehearse in any detail the development of directors' obligation to consider the interests of creditors, as that has been done previously. ${ }^{37}$ The main stages in the development of the obligation are as follows. The obligation was identified in the case law and later, in the UK, included in legislation. The seminal decision was the judgment of Mason J of the High Court of Australia in Walker $v$ Wimborne, ${ }^{38}$ where it was first stated that directors, when their company is in severe financial difficulty, must take account of the interests of the creditors of their company. This duty was owed to the company and not to the creditors and thus the creditors could not bring proceedings against errant directors. ${ }^{39}$ The essence of the case was applied in several cases in Commonwealth jurisdictions during the $1980 \mathrm{~s},{ }^{40}$ and was the basis of the decision in Liquidator of West Mercia $v$ Dodd ${ }^{41}$ by the English Court of Appeal, the first UK court to deal with the matter. The principle was employed quite frequently in Australia and elsewhere in the Commonwealth and Ireland in the 1990s and early 2000s. Until the early years of this century it was not invoked often in UK cases. However, from 2002 a sizeable corpus of UK cases has been built up in which courts have held directors liable for failing to take the interests of creditors into account. ${ }^{42}$ The last primary stage of the development of the obligation was its inclusion, in effect, in statute. After much consideration and debate the Company Law Review Steering Group (CLRSG), charged in 1998 with reviewing company law in the UK, eventually recommended the inclusion in the part of any new companies legislation that dealt with directors' duties, of a provision referring to the obligation to consider the interests of creditors. The government acceded to this recommendation and in the Companies Act 2006, s.172(3) did what was envisaged by the CLRSG. The provision stipulates that the duty set out in s.172(1) is subject to any enactment or rule of law requiring directors, in certain circumstances, to consider or act in the interests of creditors. Thus, in certain cases the obligation in s.172(3) trumps the duty in s.172(1).

Since the advent of s.172(3) there has been a significant number of cases where s.172(3) has been relied on by liquidators in bringing legal action against directors of companies that had ended up in insolvent liquidation. ${ }^{43}$ The obligation is now a settled and quite wellknown element of directors' responsibilities, and a failure to adhere to it is likely to lead

37. See eg DD Prentice, "Creditor's Interests and Director's Duties" (1990) 10 OJLS 265; R Grantham, "The Judicial Extension of Directors' Duties to Creditors" [1991] JBL 1; D Wishart, "Models and Theories of Directors' Duties to Creditors" (1991) 14 NZULR 323; J Ziegel, "Creditors as Corporate Stakeholders: The Quiet Revolution-An Anglo-Canadian Perspective” (1993) 43 U of Toronto LJ 511; Keay, Company Directors' Responsibilities to Creditors (2007).

38. (1976) 137 CLR 1.

39. This has been made clear in several cases, including Spies $v R$ (2000) 201 CLR 203.

40. See eg Grove v Flavel (1986) 4 ACLC 654; Kinsela v Russell Kinsela Pty Ltd (1986) 4 ACLC $215 ; 10$ ACLR 395; Nicholson v Permakraft (NZ) Ltd (1985) 3 ACLC 453; Jeffree v NCSC (1989) 7 ACLC 556.

41. (1988) 4 BCC 30.

42. See cases cited ante, fn.4.

43. See eg Roberts v Frohlich [2011] EWHC 257 (Ch); [2012] BCC 407; [2011] 2 BCLC 625; GHLM Trading Ltd v Maroo [2012] EWHC 61 (Ch); Re HLC Environmental Projects Ltd (in liq) [2013] EWHC 2876 (Ch); BTI 2014 LLC v Sequana SA [2016] EWHC 1686 (Ch); Ball v Hughes [2017] EWHC 3228 (Ch); Joint Liquidators of CS Properties (Sales) Ltd [2018] CSOH 24. 
to the initiation of proceedings by liquidators. What remains not clear and settled is, as discussed below, the parameters of the obligation.

The jurisprudence indicates that the test as to whether or not directors are liable under s.172(3) is subjective, as it is under s.172(1). That is, directors are not liable if they act in good faith and actually consider the interests of the creditors when making decisions while subject to the s.172(3) obligation. ${ }^{44}$ If directors fail to consider creditor interests, then, in order to ascertain whether they are liable, the court is to ask whether, in the whole of the circumstances, an intelligent and honest person in the position of the directors could have reasonably believed that the impugned action was for the benefit of the creditors. ${ }^{45}$

If the number of successful claims is anything to go by, it would appear that, in the past 15 years, directors are more likely to have been found liable for breach of duty than for wrongful trading. ${ }^{46}$

\section{RESTRUCTURING}

The focus of this paper is to determine whether restructuring is put at risk by the existence and application of s.172(3). Restructuring is "a process by which the liabilities of a company in financial difficulties are restructured so as to enable the company, and, therefore, value, to be preserved and for its business to be carried on as a going concern". ${ }^{47}$ Harris describes it as the situation "where a company has become over-leveraged with debt and needs to alter the nature of some or all of the debt obligations so as to facilitate the company to return to profitability at some point in the future". ${ }^{48}$ Restructuring may consist of several stages, which may well include the assessment of problems of the company and selection of a particular rescue option. Restructuring may take place when a company is not insolvent, but the nature of the restructuring which results will largely be determined by "the seriousness of the company's financial difficulties, the economic and credit climate at the relevant time, the nature of the obligations in question and the attitude of the company's creditors to the proposals put to them". ${ }^{49}$ Naturally the kind of restructuring that may be sought will depend on a number of elements, such as the size of the company, market conditions, the financial state of the company, and the attitude of creditors. In large companies restructuring can be extremely complicated.

The term that is often given to informal restructuring arrangements is "workout". A "work-out" is the designation of an out of court, privately arranged restructuring on a going concern basis of all, or substantially all, of a company's liabilities, laid down

44. Colin Gwyer and Associates Ltd v London Wharf(Limehouse) Ltd [2002] EWHC 2748 (Ch); [2003] BCC 885, [87] and applying Charterbridge Corp Ltd v Lloyds Bank Ltd [1970] Ch 62.

45. Ibid.

46. In some case liquidators have sought to rely on both in claims against directors. See eg Roberts v Frohlich [2011] EWHC 257 (Ch); [2012] BCC 407; [2011] 2 BCLC 625.

47. Hedger \& Howard, supra, fn.35, [1.2].

48. J Harris, "Reforming insolvent trading to encourage restructuring ; Safe harbour or sleepy hollows?" (2016) 27 J of Banking and Finance Law and Practice 294, 298.

49. Hedger \& Howard, supra, fn.35, [1.2]. 
in an agreement when insolvency looms. ${ }^{50}$ Workouts are important. From their study of small distressed UK companies, Franks and Sussman found that only 26 per cent of the companies that were part of their sample entered formal insolvency procedures ${ }^{51}$ A major benefit of a workout can be that it is able to save money as it is not as costly as restructuring in administration or other formal insolvency regimes.

Options that can be embraced are as broad as the imagination of the directors, their advisers and any parties who may be involved in the restructuring, but they usually include: debt for equity swaps, debt rescheduling, asset sales, write-offs, cost reductions, sale and lease-back of equipment and plant, injection of new capital,,$^{52}$ payment holidays and compromises. The essential aspect is that the company is restructured on the basis of contractual relations rather than being subjected to a formal insolvency procedure, although a formal procedure may be employed to implement the arrangement arrived at by the parties.

It has been asserted that whether or not a restructuring should be considered is principally a commercial judgment. ${ }^{53}$ Given the fact that there tends to be a view that judges will defer to the commercial or business judgments of directors ${ }^{54}$ it might be thought that judges will not hold directors liable for a breach of s.172(3) where restructuring has occurred. However, it must surely be the case in making that judgment that the directors have to take into account the interests of the creditors, and so a judge should be able to ascertain whether the directors did that, even though the decision to restructure is a commercial judgment. What some commentators have complained about is the extent that some courts have gone to in assessing whether the decision to restructure was appropriate or reasonable. ${ }^{55}$

The fact is that restructuring can be waylaid by a number of events and it is usually an uncertain path to take. Due to possible claims that might be brought against individual directors if a restructuring venture fails and the company ends up in administration or liquidation, directors can be in an unenviable position. The situation where an action might be taken is where directors seek to undertake the restructuring of a group of companies and one or more may not do so well out of the action as other companies and these companies enter, say, liquidation. A liquidator might argue that the creditors of a company that entered liquidation did not have their interests considered, or at least not to

50. B Wessels and S Madaus, "Rescue of Business in Insolvency Law" (European Law Institute, 2017), 75: www.europeanlawinstitute.eu/fileadmin/user_upload/p_eli/Publications/Instrument_INSOLVENCY.pdf.

51. "An Empirical Study of Financial Distress of Small Bank-Financed UK Companies", American Finance Association, 61st Annual Meeting, New Orleans, 2001, 3.

52. Harris, supra, fn.48, 298; World Bank Group and the United Nations Commission on International Trade Law, Creditor Rights and Insolvency Standard (World Bank Group, 2005) (the latter referred to in R Purslowe, "Decisions in the Twilight Zone of Insolvency—Should Directors be Afforded a Safe Harbour?" (2011) 13 U of Notre Dame Australia L Rev 113, 133).

53. Hedger \& Howard, supra, fn.35, [1.3].

54. See eg Harlowe's Nominees Pty Ltd v Woodside (Lakes Entrance Oil NL) (1967) 121 CLR 483, 493; Howard Smith Ltd v Ampol Petroleum [1974] AC 821, 832; Darvall v North Sydney Brick Darvall v North Sydney Brick (1989) 15 ACLR 230, 247; Birdi v Specsavers Optical Group Ltd [2015] EWHC 2870 (Ch). See also B Cheffins, Company Law: Theory, Structure and Operation (OUP, Oxford, 1997), 317; D Kershaw, Company Law in Context, 2nd edn (OUP, Oxford, 2011), 474.

55. Hargovan \& Harris (2013) 35 Sydney L Rev 433. 
the extent of other stakeholders of the companies who, arguably, fared well. ${ }^{56}$ An aim of the law relating to restructuring is to resolve coordination problems and to determine who has an interest in the company and to what extent that interest should be protected. ${ }^{57}$ It must not be used opportunistically in order to enable some stakeholders to benefit at the expense of others. ${ }^{58}$

\section{THE UNCERTAINTY ASSOCIATED WITH SECTION 172(3)}

Section 172(3) provides some unwelcome uncertainty for both directors and those, likely most often to be either liquidators or administrators, who are contemplating whether to proceed against directors for breach of the provision. While we have seen greater and more detailed judicial consideration of the provision, the fact is that the whole area is still in the process of development, ${ }^{59}$ and the comments made in several cases are not clear in a number of respects.

This part of the paper discusses the issues that face all interested parties and particular focus is given to the issues in light of possible restructuring.

\section{A. The when}

The first problem that provides uncertainty is ascertaining whether directors are in fact subject to the duty found in s.172(3) at any particular time. Section 172(3) does not explain when the duty arises; it is left to the case law. However, the case law is not clear on when the obligation is triggered. The issue will not be considered here, as it is something that has been examined on several occasions in some depth. ${ }^{60}$ Suffice it to say that, while it is clear that directors are subject to the duty when their company is insolvent, it is not clear when the company is in a position short of insolvency. Some of the circumstances that have been said to trigger the obligation are "doubtful solvency", "risk of insolvency" or the "vicinity of insolvency". ${ }^{61}$ While John Randall QC (sitting as a deputy High Court judge) said in Re HLC Environmental Projects Ltd (in liq) ${ }^{62}$ that all the terms just referred to add up to the same thing, ${ }^{63}$ there is uncertainty because "the absence of a defined trigger can leave directors facing very difficult judgment calls". ${ }^{64}$ While insolvency may look a more certain test than those which apply to companies whose situation is short of insolvency, this is not necessarily the case, as determining whether a company is in fact insolvent can be far

56. This was effectively the situation in LRH Services Ltd v Trew [2018] EWHC 600 (Ch).

57. S Paterson, "Rethinking the Role of the Law of Corporate Distress in the Twenty-First Century", Paper 27/2014, LSE Working Paper, Law Department, LSE, 7.

58. Ibid, 23.

59. Maslen-Stannage (2013) 31 Company and Securities LJ 76, 77.

60. See eg A Keay, "The Director's Duty to Take into Account the Interests of Company Creditors: When is it Triggered?" (2001) 25 Melbourne ULR 315. Recently the Court of Appeal in BTI 2014 LLC v Sequana SA [2019]

EWCA Civ 112, [215], held that a real risk of insolvency basis could not be the basis for the triggering of the obligation.

61. For a discussion of the timing of the duty, see ibid.

62. [2013] EWHC 2876 (Ch).

63. And approved on other occasions by, eg, by Rose J in BTI 2014 LLC v Sequana SA [2016] EWHC 1686

(Ch). But note the decision of the Court of Appeal in Sequana and referred to supra, fn.60.

64. Clifford Chance, supra, fn.9. 
from easy. Certainly it has been made clear that the question whether or not the duty in s.172(3) has arisen must be determined on a case-by-case basis ${ }^{65}$ which provides little or no certainty or even guidance.

So, often directors do not know when they are subject to the duty and office-holders are also equally unsure whether directors have in fact acted in breach of s.172(3). For the purposes of this paper it is assumed that directors are subject to the duty in s.172(3). This, it is submitted, is a reasonable assumption, for it is likely that directors will consider a debt restructuring option only if their company is in significant financial distress, because restructuring is not to be undertaken lightly and without good cause, for it is costly and can affect a company's reputation in the marketplace.

\section{B. The how}

The second problem - and this is of more concern in the context of this paper-is knowing how directors are to act if they are subject to the s.172(3) duty. How do directors fulfil their responsibility? Importantly, there is little judicial guidance for directors.

The initial point that we need to note is that the great preponderance of English authority holds that, when s.172(3) applies, the interests of the creditors are paramount. ${ }^{66}$ This appears to be the position in practice ${ }^{67}$ and recent cases have applied this view, ${ }^{68}$ while no recent cases have indicated that the creditors' interests are to be considered concurrently and to the same extent as those of others. "Paramount" means something that is more important than anything else, ${ }^{69}$ so we can conclude that the creditors' interests are to be seen as pre-eminent. Thus, this would suggest that directors must put the interests of creditors before any other concern or interest, including those of the shareholders, and even, perhaps, to the total exclusion of others' interests. ${ }^{70}$

While the holding that creditors' interests are paramount provides some guidance, in that it means that the focus is to be on creditor interests, it does not tell directors how they are to broach the whole issue. While we have comments here and there in the cases, they have generally done little to give certainty or much guidance. According to the decision in Colin Gwyer v London Wharf (Limehouse) $L t d{ }^{71}$ which has been regularly cited with approval, it was said that, in taking into account the interests of creditors, directors are to take into account the impact of their decision on the ability of the creditors to recover the

65. Dickinson v NAL Realisation Ltd [2017] EWHC 28 (Ch); [2017] BPIR 611.

66. See eg Re Pantone 485 Ltd [2002] 1 BCLC 266, [69]; Colin Gwyer v London Wharf (Limehouse) Ltd [2002] EWHC 2748 (Ch); [2003] 2 BCLC 153, [74]; Re Capitol Films Ltd (in administration) [2010] EWHC 2240 (Ch); [2011] 2 BCLC 359, [49]; Roberts v Frohlich [2011] EWHC 257 (Ch); [2012] BCC 407; [2011] 2 BCLC 625, [85]; Re HLC Environmental Projects Ltd [2013] EWHC 2876 (Ch), [89], [92]. To the contrary, see Re MDA Investment Management Ltd [2003] EWHC 2277 (Ch); [2004] 1 BCLC 217; [2004] BPIR 75, [70]; Ultraframe (UK) Ltd v Fielding [2005] EWHC 1638 (Ch), [1304]. For a discussion of the jurisprudence, see A Keay, "Directors' Duties and Creditors' Interests" (2014) 130 LQR 443.

67. Clifford Chance, supra, fn.9.

68. Eg Burnden Holdings (UK) Ltd [2017] EWHC 2118 (Ch), [63-64]; Re Bowe Watts Clargo Ltd [2017] EWHC 7879 (Ch); Angel Group Ltd v Davey [2018] EWHC 1781 (Ch), [75].

69. J Pearsall, New Oxford Dictionary of English (OUP, Oxford, 2001), 1346.

70. Keay (2014) 130 LQR 443.

71. [2002] EWHC 2748 (Ch); [2003] 2 BCLC 153, [74]. 
sums due to them from the company. ${ }^{72}$ Does taking the impact into account mean noting what the impact will be or doing something about it to ameliorate the position of the creditors? One would think that it is the latter. This was certainly implicit, if not explicit, in what Drummond AJA said in the appeal court in the Bell Group litigation (Westpac Banking Corp v Bell Group Ltd (in liq) $(\mathrm{No} \mathrm{3})^{73}$ ) when he stated that it is not sufficient for the directors to think about the interests of the creditors. ${ }^{74}$ His Honour ${ }^{75}$ pointed to the fact that in Kinsela $v$ Russell Kinsela Pty Ltd $^{76}$ Street CJ, of the Court of Appeal in New South Wales, said that directors have a duty to not prejudice the interests of creditors. Thus, Drummond AJA said that "the duty will not ordinarily be satisfied by directors who consider the impact that entry into a particular transaction by the company will have on its creditors but proceed with the transaction even though it causes significant prejudice to those creditors". ${ }^{77}$ Later his Honour said that: ${ }^{78}$

"if the circumstances of the particular case are such that there is a real risk that the creditors of a company in an insolvency context would suffer significant prejudice if the directors undertook a certain course of action, that is sufficient to show that the contemplated course of action is not in the interests of the company."

Other cases have suggested that the directors are not to be prejudiced by the action of the creditors. For instance, recently, in Joint Liquidators of CS Properties (Sales) Ltd, ${ }^{79}$ Lord Bannatyne adopted the statements in a leading book on directors ${ }^{80}$ that the interests of creditors are prejudiced if anything occurs that will or may compromise the company's ability to pay its debts when they are due. The text approved by the judge went on to say that, before undertaking any action, the directors should have regard to the value to be derived from the action and any potential prejudice to the creditors' interests generally. ${ }^{81}$

It is clear from the cases that, for a director to be in breach, there is no need to establish that he or she deliberately ignored the interests of the creditors; if it does not occur to the director to take account of a creditor's interest, then that would suffice for a potential breach. ${ }^{82}$ This suggests that in a restructuring context the directors have to be careful to weigh up the creditors' interests and to determine, as far as they can, what might prejudice those interests.

Can we say that taking into account the interests of creditors is akin to the directors in s.172(1) being required to have regard for the factors set out in paragraphs (a)-(f) of that provision, or does it mean something different? It is submitted that it is different because in s.172(1) it is not those factors but the interests of the members that are the end concern

72. Ibid, [81].

73. [2012] WASCA 157.

74. Ibid, [2041].

75. Ibid, [2041].

76. (1986) 4 ACLC 215; 10 ACLR 395; 4 NSWLR 722, 730.

77. [2012] WASCA 157, [2042].

78. Ibid, [2047]

79. [2018] CSOH 24. See also Nicholson v Permakraft (NZ) Ltd (1985) 3 ACLC 453

80. S Mortimore, Company Directors: Duties, Liabilities, and Remedies, 3rd edn (OUP, Oxford, 2017), [12.63].

81. Ibid, [12.97]

82. Colin Gwyer v London Wharf (Limehouse) Ltd [2002] EWHC 2748 (Ch); [2003] 2 BCLC 153, [78]; Re HLC Environmental Projects Ltd [2013] EWHC 2876 (Ch), [89]. 
of directors. Whereas under s.172(3) the interests of the creditors are not to be regarded in achieving some other objective, the end concern of the directors would appear to be the creditors' interests. As indicated above, the case law suggests in many places that the directors are to consider the impact actions might have on creditors and they are not to prejudice the creditors. This suggests something more than merely having regard to creditor interests. Drummond AJA, who provided the most forthright of the judgments in the appellate court in Westpac Banking Corp v Bell Group Ltd (in liq) (No 3), ${ }^{83}$ said that directors have a duty to ensure that creditor interests are properly protected and not to have their interests considered merely as one of a number of stakeholder groups. ${ }^{84}$ This latter comment probably accords with s.172(3). Thus, to comply with s.172(3) it would appear that the interests of the employees would not be taken into account in any directorial decision if that were to prejudice creditors.

\section{Which creditors?}

Thus far we have established that creditors' interests are paramount. But then we come to asking: which creditor interests are to be considered in any restructuring proposal? All or only some? On occasions this can be difficult. Much will depend on the position of the creditors, how much they are owed and what are the conditions relating to the restructuring. Of course, it would be optimal if the directors of the company could finalise a restructuring plan before taking any action that might favour one class of creditor over another, but that would rarely be possible.$^{85}$ Clearly, if they do contemplate a restructuring, they must consider creditors' interests, but we come back to the issue of which creditors?

A problem that can arise in relation to determining which creditor interests are to be considered is, in many companies and very possibly with a restructuring, the fact that not all creditors will be of the same type, and, critically, some will have different interests. For example, there are likely to be significant differences between the interests of a bank with a charge over company assets compared with unsecured trade creditors. There might well even be a difference within actual classes of creditor. For instance, the interests of an unsecured creditor who has lent money to the company may well have a different perspective on an arrangement from that of a trade creditor, such as one who has built its business around supplying the company. Different creditors may well have different agendas and they are dealt with in different ways by the law, particularly on winding up. ${ }^{86}$ Thus, what is in the best interests of the creditors is, potentially, an even more complex issue where there are creditors with different aims and interests. Nevertheless, directors cannot be taken to know of the preferences of creditors unless they have been expressed to them or they are obvious. Absent this, directors would probably be expected to turn their mind to the legal rights that creditors have and might have if there were a liquidation of the company.

83. [2012] WASCA 157.

84. Ibid, [2029].

85. Maslen-Stannage (2013) 31 Company and Securities LJ 76, 80.

86. This issue is dealt with in greater depth in Keay, Company Directors' Responsibilities to Creditors (2007), 235-241. 
Some assistance might be had from the area of schemes of arrangement, ${ }^{87}$ where there may be multiple groups of creditors with different interests and expectations and these may well conflict. It is contended that the comments of Mann $\mathrm{J}$ in Re Bluebrook Ltd, ${ }^{88} \mathrm{a}$ scheme of arrangement case, are important for the purpose of this paper. In this case a scheme of arrangement was proposed, which restructured a group of companies in the interests of the senior lenders and left the mezzanine lenders in one company in the group without any benefit. The mezzanine lenders opposed the application to court for approval of the scheme. One of the grounds was that the directors had breached their duty in failing to promote the interests of the mezzanine lenders. Counsel for the mezzanine lenders argued that directors of an insolvent company do not owe duties to particular sections of the creditors only. ${ }^{89}$ The judge accepted that but rejected the claim on the basis that the mezzanine lenders were "out of the money" in that they had no economic interest in the company..$^{90}$ An example of what directors must do or not do falls from what Mann J said, namely that, if a company is insolvent, then a consideration of whether or not to preserve the business as a going concern must be guided by the interests of the creditors and not by consideration of the interests of some third party who has no claim. ${ }^{91}$ The judge said that the directors: ${ }^{92}$

"entered into arrangements with the section of secured creditors with priority over subordinated creditors who, on the facts as known to them, would not have any interest in the assets because of their subordination. That is entirely different from the situation where directors advance the cause of one creditor at the expense of other creditors who thereby lose a benefit they would otherwise have."

It is submitted that the upshot of what his Lordship said in relation to schemes can be applied to directors considering creditors in an insolvency type situation and particularly where a restructuring is being considered. Applying what his Lordship said in this context, directors are to take into account the commercial realities of the company and they do not have to consider the interests of those creditors who are "out of the money", namely someone who has no possibility of recovering money owed, even in a liquidation. Of course, it may not be possible in many cases for directors to know which creditors' money is effectively at stake and, therefore, who is in the money, so that is always something of which they must be wary. Sometimes the value of a creditor's interest may be difficult to ascertain. The recent decision of HH Judge Mathews (sitting as a High Court judge) in Wessely $v$ White $e^{93}$ may speak to this in that his Lordship said that in dealing with s.172(3) a subjective test applies to what directors have done and as to whether there has been a breach of duty where "no material interest has been overlooked". ${ }^{94}$ If a creditor is out of the money, then he or she does not hold a material interest and, it follows, can be overlooked.

87. Addressed by the Companies Act 2006, Part 26.

88. [2009] EWHC 2114 (Ch); [2010] 1 BCLC 338.

89. Ibid, [67].

90. Ibid, [25], [80] and referring to Re Tea Corp Ltd [1904] 1 Ch 12.

91. [2009] EWHC $2114(\mathrm{Ch})$, [67].

92. Ibid (emphasis in original).

93. [2018] EWHC 1499 (Ch).

94. [2018] EWHC 1499 (Ch), [40]. 
So, where a company is insolvent and it has, besides general unsecured creditors, creditors of another class, such as one or more secured creditors, it might be argued that, if the company's funds/assets do not cover the debts owed to the secured creditors, the directors should not take into account the unsecured creditors' interests, as their money has gone, just like the shareholders' funds. That is, they are out of the money, and any trading would involve using the funds of the secured creditors and it would be at their risk. In such a position it might be thought appropriate that, in order to protect the interests of the secured creditors, the directors should take the company into administration or liquidation. To trade on and risk further funds might suit junior and unsecured creditors who have the hope that the company might be turned around, but it would not usually be favoured by secured creditors. Of course, it is not always possible for the directors to ascertain easily at a given moment whether or not the company has funds/assets that exceed the liabilities owed to the secured creditors. However, one would think that, if there is concern over the financial position of the company, it would be prudent of the directors to discover the exact situation so that they could take into account the interests of the appropriate group(s) of creditors from a strong position of knowledge.

While it would seem that directors might ignore the interests of creditors where they are not in the money and by some way, Re Bluebrook $L t d^{95}$ clearly provides that the directors must ensure that they do not discriminate between creditors within a particular class. This is a sentiment that has been stated in the cases involving the director's obligation to creditors. In Re Pantone 485 Ltd ${ }^{96}$ Richard Field QC (sitting as a deputy High Court judge) said that a director is not in breach if he or she acts consistently with the interests of the general creditors but inconsistently with the interests of a creditor or a section of creditors with special rights in a liquidation; hence, it follows that, if a director favours one creditor or a section of creditors to the prejudice of the general creditors as a whole, then he or she is in breach. This approach was followed by Newey $\mathrm{J}$ (as he then was) in GHLM Trading Ltd v Maroo, ${ }^{97}$ when he said that, where a company is insolvent, the director's duty involves having regard for the interests of the creditors as a class. His Lordship said that: "If a director acts to advance the interests of a particular creditor, without believing the action to be in the interests of creditors as a class, it seems to me that he will commit a breach of duty" ${ }^{98}$ HHJ Pelling QC (sitting as High Court judge) said in Capital for Enterprise Fund A LP v Bibby Financial Services Ltd ${ }^{99}$ that:

"However, the emphasis of that duty is on the obligation to manage the affairs of the company having regard to the interest of creditors as a class. It does not entitle a director, much less a director acting alone and without board approval, to operate in a manner that prefers the interest of one creditor over those of another and much less in a manner that defeats the interest of creditors generally."

Conversely then, we might conclude that a director can advance the interests of a specific creditor, provided that he or she believes that it will be in the interests of creditors

95. [2009] EWHC 2114 (Ch); [2010] 1 BCLC 338.

96. [2001] EWHC 705 (Ch); [2002] 1 BCLC 266, [73].

97. [2012] EWHC 61 (Ch); [2012] 2 BCLC 369.

98. Ibid, [168].

99. [2015] EWHC 2593 (Ch), [89] (emphasis in the original). 
as a class. If one or more creditors benefit from a restructuring at the expense of others, this suggests that there is a breach, except where the latter were out of the money.

In the Western Australian Court of Appeal in Bell Group, ${ }^{100}$ a case to which we come next, the majority view of the court suggested that every creditor's interest needs to be taken into account. Some commentators have suggested that that view is unworkable. ${ }^{101}$ But surely it is not unworkable to take every creditor's interest into account; directors might, after doing so, then decide to ignore the importance of some interests and restructure in a way that some lose out, as that is the only reasonable way forward. In such a situation it would be advisable for the directors to make it clear in some way that they have considered the interests of all the creditors before taking the action that is later impugned.

\section{THE BELL GROUP LITIGATION}

One of the few examples that we have in the case law of a restructuring which led to actions by liquidators for breach of the duty that is the subject of the paper emanates from the litigation concerning Bell Group Ltd. The liquidators of this company's claim against directors and banks involved in the restructure came before the Supreme Court of Western Australia ${ }^{102}$ and then went on appeal to the Western Australian Court of Appeal. In this case, the liquidators of the Bell Group and subsidiaries brought an action based on a number of grounds. One of them was that there had been a breach of duty to consider creditor interests. The action was initiated against directors and others. The case was a very complex one and the judgments at first instance and on appeal are exceptionally long, covering various duties of directors and related issues. It is not possible to address all matters of interest in the confines of this paper. The following focuses on major issues and comments that appear to contribute to the aim of the paper.

The facts, briefly, are as follows. In the late 1980s the Bell Group began to experience financial difficulties and, to address this, several loan facilities were made available to it by banks and other financial institutions. The Group honoured obligations to repay but did so with some difficulty. In 1989 the Group commenced negotiations with its banks in order to obtain a restructuring agreement. At the time, the banks were owed approximately A $\$ 262 \mathrm{~m}$ and bondholders A $\$ 540 \mathrm{~m}$. All were unsecured. Discussions were had concerning the banks taking security over assets that were not at that time subject to security. If liquidation occurred, then the banks would only rank with bondholders, of whom there were many. The upshot was that refinancing arrangements were agreed and, inter alia, these subordinated the rights of the bondholders to the banks, which were granted security over company assets if insolvency procedures were commenced, and they also provided that the banks would benefit from sales of company assets. The loan facilities that were already in place were extended. All of this improved the position of the banks substantially. The aim of the negotiations was to give the Group time in which to restructure its affairs so that the Group was viable. However, subsequent to the restructuring, the financial position

100. [2012] WASCA 157.

101. See Maslen-Stannage (2013) 31 Company and Securities LJ 76, 81.

102. Bell Group Ltd (in liq) v Westpac Banking Corp (No 9) [2008] WASC 239. 
of the Group worsened considerably and liquidators were appointed. The banks' response was to seek to enforce the security interests that they held over Group assets. Earlier the banks had made other recoveries, and, overall, the banks recouped $\mathrm{A} \$ 283 \mathrm{~m}$.

The Group liquidators made a number of claims against the directors and the banks. Inter alia, they argued that the directors, knowing that the Group was insolvent, were in breach of their duty to act bona fide in the best interests of the company, in that they failed to consider the interests of the creditors. It was also alleged that the banks were liable under both limbs of the decision in Barnes $v$ Addy, ${ }^{103}$ namely that they knowingly received trust property and they participated in a breach of trust, that is, in this case a breach of duty. Eventually the liquidators decided not to proceed against the directors.

In a mammoth judgment, ${ }^{104}$ Owen $\mathrm{J}$ found for the liquidators on a number of grounds, but importantly that the directors were in breach of their duty to consider the interests of the creditors and the banks were aware of this. The actions of the directors were held by his Honour to have prejudiced the external creditors of the Group.

The banks appealed, but again lost. ${ }^{105}$ In the appeal court, Drummond and Lee AJJA dismissed the appeal, although the other member of the court, Carr AJA, would have allowed it.

Arguably, there are aspects of the Bell Group case and the present state of Australian law, especially in light of that decision, that make it distinguishable in any UK consideration of restructuring, so we must be careful in considering and even applying the comments of the judges in Bell Group. It must be remembered that the creditor interest element of the duty in Australia is not codified, unlike in the UK. Also, unlike in the UK, where the predominant view has been that when s.172(3) applies the interests of the creditors are paramount, a view that applied before the introduction of s.172(3), Owen J did not accept that view. His Honour felt that paramountcy would come perilously close to replacing the duty to act in the best interests of the company with a duty to act in the interests of creditors. ${ }^{106}$

In his judgment in the appeal court, Lee AJA, a member of the majority, was concerned that the directors had not inquired as to how the refinancing arrangement would affect the non-bank creditors of the company, and this meant that they had failed to consider the interests of the creditors as a whole. ${ }^{107}$ Carr AJA, in dissenting, was of the view that a successful restructuring could have saved the business and this would then have benefited all creditors, so the directors' actions were acceptable. ${ }^{108}$

It may be important that in this case there were non-bank creditors whose interests were not considered to be "out of the money" when the restructuring was discussed and implemented.

103. (1874) LR 9 Ch App 244.

104. Bell Group Ltd (in liq) v Westpac Banking Corp (No 9) [2008] WASC 239.

105. Westpac Banking Corp v Bell Group Ltd (in liq) (No 3) [2012] WASCA 157.

106. [2008] WASC 239, [4439]

107. [2012] WASCA 157, [1092].

108. Ibid, [2902]. 
It has been asserted that the majority in the appeal court, unlike Owen $\mathrm{J}$ at first instance, applied a creditor primacy approach. ${ }^{109}$ This appears to be correct. Whilst the majority considered the issue of how directors are to act when their company is insolvent or near to it covered the duty in more depth than the English case law has done thus far, the vast majority of English cases advocate a similar approach in that, as we have seen, they see creditor interests as paramount. Nevertheless, the approach in UK cases has not gone as far as the majority in the appeal in Bell Group in laying down such a hard test for directors. In the UK it has been clearly stated that, provided that the directors acted in good faith and considered the interests of the creditors (as paramount), then they will not be held liable. Arguably this provides a form of informal business judgment rule, that is, if you act in good faith and consider the creditors' interests the court will not second guess what you decided to do. Yet, in Bell Group Drummond AJA stated that "courts would intervene in an appropriate case, irrespective of the directors' beliefs and business judgments, to ensure that the creditors are properly protected". ${ }^{110}$ An English judge could not hold to such a proposition, on the state of the existing case law, as he or she would not find a director liable if he or she acted in good faith.

\section{AN ASSESSMENT}

The above discussion has highlighted the fact that the elements of the obligation in s.172(3) are not precise. Importantly for the purposes of this paper, it is not clear what directors must do to ensure that they are regarded as fulfilling the requirement to consider the interests of creditors, and this may produce apprehension in directors in deciding whether to propose restructuring. What is at least clear is that all concerned are still somewhat in the dark about how the duty in s.172(3) is to be discharged. This concern can be exacerbated where directors are considering a restructuring, because, unlike many actions that they will take as directors, a whole host of issues may have to be factored into any proposed actions. It is often not going to be as simple as directors having to decide whether to embark on a particular project and whether that would be beneficial for creditors.

The first thing we can say with a reasonable amount of certainty is that, when subject to s.172(3), the creditors' interests are likely to be regarded as paramount by an English court, and perhaps by other UK courts. Thus, any restructuring cannot be justified on the basis that it would benefit shareholders or other stakeholders if it did not benefit creditors overall. In putting a restructuring in place, the directors could only do so and remain free from liability if they could establish that they did so to further the interests of the creditors. The interests of other stakeholders should not come into the decision if doing so was to reduce the benefits of the creditors. Section 172(3) trumps s.172(1) when insolvency or financial distress exists, meaning that the duty of the directors to promote the success of

109. Hargovan \& Harris (2013) 35 Sydney L Rev 433, 445. In contrast, the trial judge applied a broader approach, saying that shareholder interests as well as creditor interests were to be considered: [2008] WASC 239, [4438-4439].

110. [2012] WASCA 157, [2031]. 
the company for the benefit of the shareholders and the taking into account of the factors set out in s.172(1)(a)-(f) are not relevant matters.

While directors may find it difficult to ascertain what they should do in considering the interests of the creditors, particularly when weighing up the possibility of a restructuring, it is submitted that the law, as it has developed, is not likely to lead to a director's being held liable for breach of s.172(3) where the director acted in good faith in entering into a restructuring arrangement after giving consideration to the interests of creditors; this would be the case even if the director were to have misjudged the effect of a restructuring on the interests of creditors. The issue is always whether the director honestly believed that the action was in the interests of the creditors, and this is the test even if the director was naïve. ${ }^{111}$ Directors are not going to be held liable necessarily for pursuing what may be thought by some, including the judge, to be a risky or inappropriate restructuring; it will depend on their view at the time of the institution of the restructuring and whether they considered the interests of creditors. Essentially then, s.172(1) in relation to solvent companies and s.172(3) in relation to those in distress, provide that the business judgments of directors are not subject to review provided that the directors acted in good faith and considered the interests of the stakeholders in s.172(1)(a)-(f) (for solvent companies) or creditors (in distressed companies). This chimes with the fact that directors do need to act according to their discretion to be able to manage their companies properly. Undoubtedly, directors need to retain discretion in order to consider and implement appropriate restructuring mechanisms, but this discretion should not be used as a reason to put assets out of reach of creditors, to squirrel away assets or money for themselves or their associates to the detriment of the creditors, or to make arrangements that might benefit the directors in the long run, such as currying favour with one group of creditors (associated with the directors or otherwise). Even if directors did not consider the interests of creditors or failed to consider all appropriately qualified creditors, then an objective test is applied, but they will not be liable if the restructuring plans were such that a reasonable person would be likely to put in place while taking account of creditors' interests.

While all of this would seem to assuage the fears of directors, it must be noted that a court can evaluate the evidence and the court may disbelieve directors when they assert that they acted in good faith and considered the interests of the creditors. So, to be clear of liability, directors cannot merely claim that they acted in good faith and considered the interests of the creditors. Their actions and decisions can be scrutinised in determining that they were consistent with acting appropriately. This means that there are some objective considerations that may come into play.

If directors do restructure on the basis that no creditors benefited, or only some creditors benefited and others lost out, and a judge can say that the directors did not actually take into account the interests of the creditors, directors may still not be liable, for the court must then assess the directors' actions objectively and decide what a reasonable person in the circumstances would have done. The judge may come to the conclusion that what the directors did was what a reasonable person would have done in the circumstances. Thus,

111. Re HLC Environmental Projects Ltd [2013] EWHC 2876 (Ch), [91]; Wessely v White [2018] EWHC 1499 (Ch), [40-42]. 
attempts at restructuring should not lead to directorial liability provided that the attempts were not unreasonable. The worst case scenario for a director, namely liability being imposed, will occur only if he or she had not taken into account the creditors' interests and had not acted in a way that a reasonable person would have acted given the interests of the creditors.

The fact is that, where restructuring is contemplated, the company is usually in a position where there is a real risk of prejudice to the company's ability to pay its creditors; restructuring is never guaranteed to satisfy all ills. There will be risk. What creditors may say is that the restructuring effort would never have given them more than if there was a liquidation or that the risks attached to the restructuring were such that creditors were unlikely to benefit. Obviously, the exact factual situation related to a restructuring needs to be considered carefully. It will be necessary for directors to weigh up the likely success of a restructuring, given the state of the company's financial affairs and the information and advice available to them. In so doing, the benefit for the creditors must be in the minds of the directors and not the continuing viability of the business, ${ }^{112}$ or the interests of others, such as the employees. ${ }^{113}$ The reason is that the creditors' interests are paramount.

One other matter needs to be considered. It is submitted that the argument that is frequently put, that directors are more likely to embrace administration or liquidation than explore the restructuring of the company if there is a chance that they might fall foul of s.172(3), is a little far-fetched. Taking a company into administration or liquidation is sometimes portrayed as the easy way out for directors. Yet is it? Undoubtedly, it is likely that there will be cases where directors have taken their company into administration or liquidation prematurely for fear of liability, but it has not been demonstrated by any broad empirical evidence or even a study of the case law that this is a frequent occurrence, or even that doing so will necessarily lead to a suboptimal outcome, as asserted by some. ${ }^{114}$ In fact, there are often good reasons why a formal insolvency process is not initiated. Formal insolvency procedures will lead to consideration of what the directors did or did not do, and their questioning by the administrator or liquidator. There is also always the possibility of legal proceedings being instituted against them. In many ownermanaged companies, in particular, the directors may be concerned that they have not always done everything according to the book and their past actions may not pass muster. Disqualification proceedings could follow the insolvency of any type of company, and the taking of a company into insolvency processes is likely to be a black mark against the director's name, especially in the labour market for directors.

Concern has been expressed that directors may be dissuaded from attempting to obtain a restructuring of the company where it seems unlikely to succeed because of the way the law has developed, and will put the company into administration, but when all is said and done that was surely one of the ideas behind administration. That is, directors could embrace administration where the company was in substantial financial difficulty and was either insolvent or likely to become so. Administration enabled insolvency practitioners to try to effect a restructuring while the company benefited from a stay on proceedings

112. Sydlow Pty Ltd v Melwren Pty Ltd (1993) 13 ACSR 144.

113. But see the decision of Hoffmann J in Re Welfab Engineers Ltd [1990] BCC 600.

114. Hargovan \& Harris (2013) 35 Sydney L Rev 433, 445. 
against it. Admittedly, in administration any sales of businesses or assets may be seen as distressed sales which will produce fewer funds than might be secured from a workout outside of a formal insolvency procedure. Yet restructuring in administration which might generate fewer returns than a workout is better than a failed workout as far as the creditors are concerned or a workout that does not address the interests of all creditors. It has been asserted that merely because a rescue attempt is unlikely to be successful should not of itself prohibit directors from attempting to save the company and preserve the business and employees' jobs. ${ }^{115}$ If it prohibited, then it is further argued that it would drive more companies into administration or liquidation and impact on strategies for rescue and would be lead to a suboptimal outcome. ${ }^{116}$ There has been no study that has unequivocally established, or even come close to establishing, that companies that could have survived were dumped into administration or liquidation.

While one can understand the concern of commentators and practitioners that informal rescue should not be taken off the table, one wonders whether the role of administration is overlooked. Inter alia, it is there to provide for a rescue of the company or of one or more of its businesses. Indeed, one of the ideas behind administration was for an administrator to consider whether a company that was insolvent or likely to become so could be rescued. In fact administrators may well have the experience and be in a better position than the directors to make dispassionate and informed decisions about a possible restructuring of a company. The possible danger is that those dealing with the company in administration may conceivably be able to cut a better deal, but surely most finance providers and other substantial companies will know that the company is in financial difficulty and needs funds to rescue itself, and so they are able to demand good terms.

The message is that restructuring should not be eschewed. It is possible that a particular form of restructuring could benefit the creditors as a whole. The difficulty is determining who is likely to benefit and who is not. Directors then have to make a decision based on good faith. This may well involve taking professional advice as to the effects of restructuring and the financial implications. If a decision is made partly or wholly because the directors want to make sure that certain creditors benefit, perhaps because the directors wish to deal with them in the future either in relation to the company in distress or in relation to some other venture, and other creditors lose out, then there is likely to be a breach.

As the appeal court majority in Bell Group went further in protecting creditors than UK courts have done hitherto, the concern about restructuring being stymied by the current state of the law is not as great in the UK as in Australia and so the concerns of Australian commentators may not be relevant to the position in the UK. Section 172(3) is designed to prohibit risky ventures being embraced, and that is often obvious, but it is not to prevent restructuring provided that the attempt is reasonable and has a fair chance of success. 


\section{CONCLUSION}

One of the ways the law has sought fit to protect creditors of companies is to require directors to take into account the interests of creditors when making decisions for their company and at a time when the company is insolvent or at least in significant financial difficulty. This protection is now found in s.172(3), which, with the common law developments that underpin it, has clearly benefited a number of creditors over the years where directors have acted inappropriately. However, the existence of the provisions can mean that directors can find themselves in an invidious position where their company is near to becoming or is insolvent. Unfortunately for all concerned, in relation to whatever actions directors may take, the courts have not, and possibly could not, provide directors with signal beacons ${ }^{117}$ as to how they should act, that is, how they should take into consideration the interests of creditors. This can make directors very wary of implementing a restructuring, in case they end up being held liable. Engaging in the process of restructuring could lead to failure, and the creditors getting less than they would have received had the company entered a formal insolvency regime rather than being restructured.

Thus far, we do not appear to have had any cases that have got to trial and been reported in some form in the UK where directors have been held liable for breaching s.172(3) when they have engaged in some form of restructuring. This does not mean that directors have not been the subject of claims by office-holders or actually been sued. Office-holder demands could have been met by directors or actions could have been discontinued against directors because a settlement has been arrived at. Another reason why there are no cases is that directors have acted appropriately after considering the interests of all of the creditors.

This paper essentially finds that, while directors may be subject to liability in entering into restructuring attempts, this is only going to occur in limited cases and so there should not be particular concern over liability of directors in relation to restructurings. This is because, first of all, courts will not hold directors liable if they acted in good faith and took into account the interests of creditors, and regarded these interests as paramount in their considerations. Even if the directors failed to take into account the interests of creditors or failed to make them paramount, they will not be liable where the court finds that a reasonable person in their position, and taking into account creditors' interests, would have entered into the restructuring. Obviously, if directors restructure in such a way as to benefit themselves or specific creditors, or they have improper motives, then liability is more likely to ensue. But, where the directors have acted reasonably, then they should be safe from challenge and the existence of s.172(3) should not deter directors from contemplating and implementing restructuring where appropriate.

117. North American Catholic Educational Programming Foundation Inc v Gheewalla (2007) 930 A 2d (Del) 101. 